DOI: 10.20535/2522-1078.2021.1(9).240544

УДК $007: 304: 659.3$

Надходження до редакції: 18.10.2020

Прийняття до друку: 06.12.2020

Балюн О. О.

канд. іст. наук, доц. кафедри видавничої справи та редагування Видавничо-

поліграфічного інституту,

КПІ ім. Ігоря Сікорського,

м. Київ, Украӥна, o.baliun@gmail.com

ORCID: 0000-0002-7676-9049

\section{Проданчук О. В.}

магістр кафедри видавничої справи та редагування Видавничо-

поліграфічного інституту,

КПІ ім. Ігоря Сікорського, м. Київ,

Украӥна, oksanaprodancuk@gmail.com
Baliun O.

PhD of Historical, Associate Professor

at the Department of Publishing and Editing,

Publishing and Printing Institute of Igor Sikorsky

Kyiv Polytechnic Institute, Kyiv, Ukraine,

o.baliun@gmail.com

ORCID: 0000-0002-7676-9049

Prodanchuk O.

Master of the Department of Publishing

Studies, Institute of Publishing and Printing

of the of Igor Sikorsky Kyiv Polytechnic

Institute, Kyiv, Ukraine,

oksanaprodancuk@gmail.com

\title{
ОСОБЛИВОСТІ ФОРМУВАННЯ ПОЗИТИВНОГО КОНТЕНТУ В СОЦІАЛЬНИХ МЕРЕЖАХ ПІД ЧАС ДОМІНУВАННЯ ПАНІЧНИХ НАСТРОЇВ НАСЕЛЕННЯ
}

THE PECULIARITIES OF FNG POSITIVE CONTENT IN SOCIAL NETWORKS DURING THE DOMINANCE OF THE PANIC MOOD AMONG POPULATION

У статті пропонується розглянути вплив негативної та недостовірної інформації про пандемію коронавірусу COVID-19 на психологічне здоров'я українців, що спричиняє формування панічних настроїв серед населення. У контексті дослідження було з'ясовано, що наслідком цілеспрямованого впливу різних комунікаційних технологій, які застосовувались з метою дезінформації, стала психоемоційна дестабілізація людини, що виявлялось у підвищеному рівні тривожності, посиленні панічних настроїв населення. Виявлено, що одним із головних каналів розповсюдження інфодемії стали соціальні мережі. Аналіз результатів соціологічних досліджень, які проводили різні дослідницькі організації, свідчить, що найвищий рівень підвищення загальної тривожності та панічних настроїв під час пандемії відбувався навесні 2020 року. Рівень недовіри до владних структур, не зважаючи на їх активну комунікацію з населенням, був достатньо високим. Користувачі соціальних мереж були більш схильні до поширення неправдивого контенту, що сприяло ще більшому

(c) Автор(и), 2021.

Видавець КПІ ім. Ігоря Сікорського, 2021. 
нагнітанню та залякуванню. Водночас з поширенням інфодемії в українському суспільстві набуває обертів процес формування добровільної протидії міфам, чуткам, неправдивій інформації з боку різних громадських, благодійних організацій, а також індивідуальних ініціатив свідомих громадян. Це дозволяє говорити про тенденції розвитку соціальної згуртованості та потребу суспільства у позитивній інформації, яка буде сприяти соціальному оптимізму. Результати дослідження виявили, що в медійному просторі, зокрема соціальних мережах, формуються тренди створення платформ соціальної підтримки та виключно позивного контенту, протидії фейковій інформації; в публікаціях використовується більш емпатійний тон; збільшується кількість месиджів про взаємодопомогу та взаємоповагу.

Ключові слова: інфодемія, пандемія, медіа, соціальні мережі, паніка, контент, фейки.

The article considers the impact of negative and inadequate information concerning the COVID-19 coronavirus pandemic on the psychological state of Ukrainians, causing panic among the population. In the context of the study, it was revealed that purposeful influence of various communication technologies, aiming at misinformation, has resulted in the psychoemotional destabilization, declaring itself as an increased level of uncertainty and panic mood among population. It was revealed that social networks have become one of the main channels for disseminating infodemic. The analysis of the results of sociological studies conducted by various research organizations shows that the highest level of general anxiety and panic during the pandemic occurred in the spring of 2020. The level of distrust in the authorities, despite their active communication with the population, was quite high. As a result, social mdia users were more inclined to spread fake content, furthering more harassment and intimidation. At the same time, with the spread of infodemic in the Ukrainian society, the process of forming voluntary counteraction to myths, rumors, fake information from various public, charitable organizations, as well as individual initiatives of conscious citizens is gaining momentum. This allows us to talk about the trends in the development of social cohesion and society's need for positive information that will promote social optimism. The results of the study have revealed that in the media space, particularly in social networks, there are the trends of the creation of platforms for social support and exclusively positive content, countering fake information; publications use a more empathetic tone; the number of messages about mutual assistance and mutual respect is increasing.

Keywords: infodemic, pandemic, media, social networks, panic, content, fakes.

Постановка проблеми. Пандемія коронавірусу COVID-19 спричинила такі глобалізаційні процеси як масове поширення істерії, страху, депресії. В умовах нестабільної соціально-економічної ситуації та масової загрози життю населенню планети, яка виникла одночасно 
в більшості країн, формується і поширюється посередництвом медіа здебільшого негативна інформація, яка спричиняе погіршення психологічного стану людини та розвиток панічних настроїв.

У період березень-травень 2020 року поширювався переважно фейковий, негативний контент, оскільки відчувався тотальний брак інформації про сам вірус, методи лікування, спроможності медичної системи витримати збільшення кількості хворих. Невизначеність ситуації, абсолютна відсутність розуміння наслідків для економіки в цілому та для добробуту кожної окремої родини або людини підвищували рівень тривожності та посилювали панічні настрої населення. Одночасно зі збільшенням хвилі неправдивого, маніпулятивного контенту зароджувалась тенденція до підвищення рівня соціальної згуртованості, зокрема, в соціальних мережах формувалися групи підтримки від підприємців, волонтерів, митців. Запит суспільства на позитивний, якісний і цікавий контент дозволяе говорити про формування нового медійного тренду в соціальних мережах, а саме соціальної підтримки, соціальної відповідальності, протидії фейковій інформації,використан няемпатичного тону.

Актуальним напрямом дослідження є аналіз впливу позитивних новин на формування настроїв населення на прикладі вивчення українського досвіду реалізації соціальних проектів, ініціатив у соціальних мережах під час пандемії коронавірусу COVID-19.

Огляд літератури. Окреслена тематика є багатоперспективною, її актуальність спонукає науковців до проведення теоретико-практичних досліджень, які у подальшому стануть цікавими напрямами наукових дискурсів. Одними з перших науковців, які описали так званий ефект ноцебо, коли негативні новини про COVID-19 у медіа незадовільно впливають на психологічний та фізичний стан людини, стали Д. Хардман (Doug Hardman), Дж. Онгаро (Giulio Ongaro) та Ф. Хатчінсон (Phil Hutchinson) [18].

Більшість наукових публікацій, які вийшли за півроку від початку пандемії, стосуються наслідків їі впливу на розвиток економіки [7], громадянського суспільства [6], дотримання прав людини [12]. Медіаплив у контексті психологічних досліджень вивчають Л. Найдьонова [10], М. Слюсаревський [14], О. Дроздов, М. Дроздова [3].

Розвиток та досвід переживання COVID-19, які спричинили та ще більше актуалізували вагомі питання медіаграмотності, особливостей 
формування та впливу позитивного та негативного контенту на людину, потребують подальших комплексних наукових досліджень.

Мета дослідження - визначити та узагальнити основні аспекти формування позитивного контенту в соціальних мережах під час пандемії коронавірусу COVID-19 через реалізацію соціальних проектів та ініціатив.

Результати дослідження. Серйозним викликом людству стала світова пандемія коронавірусу COVID-19, яка спричинила не тільки глобальні трансформаційні процеси у всіх галузях суспільного життя, але й викликала емоційну трансформацію. Інформація негативного забарвлення як від авторитетних медіа, так і від користувачів соціальних мереж змушує людей знаходитись у режимі очікування чогось поганого. Директор Всесвітньої організації охорони здоров'я Т. Гебреісус запропонував термін «інфодемія» - поширення дезінформації, чуток, нагнітання й залякування у масмедіа під час спалахів пандемій, що спричиняє утруднення отримання достовірної інформації в умовах інформаційного шуму.

Дослідниця Л. Найдьонова зазначає, що під час карантину найбільш поширеними медіапсихологічними феноменами стали: тривожний інформаційний вир, пересиченість медіапотоками, поляризація і консервація негативного спілкування [10].

Варто звернути увагу на особливості медіаспоживання в Україні в 2020 році. Згідно з дослідженнями соціологічної компанії InMind «Ставлення населення України до ЗМІ та споживання різних типів медіа у 2020 році» виявлено, що $62 \%$ респондентів дізнаються новини з соціальних мереж. Платформа Facebook як джерело новин посідає першу позицію в рейтингу; YouTube все більше використовується як альтернатива телебаченню. Месенджер Telegram найчастіше використовують для отримання коротких новин, можливості бути в курсі подій [17].

За результатами опитування, найбільший інтерес до інформації про коронавірус був у перші місяці введення карантину. Саме у березнітравні 2020 року збільшилась кількість користувачів соціальних мереж, які були охоплені панічними настроями. Підтвердженням цієї тези є результати дослідження дописів користувачів соціальних мереж (Facebook та Instagram), проведеного Центром контент-аналізу, які свідчать про підвищення загальної тривожності та панічних настроїв під час пандемії. Фейкова та маніпулятивна інформація з ненадійних джерел збільшувала рівень панічних настроїв(див. мал. 1) [4]. 


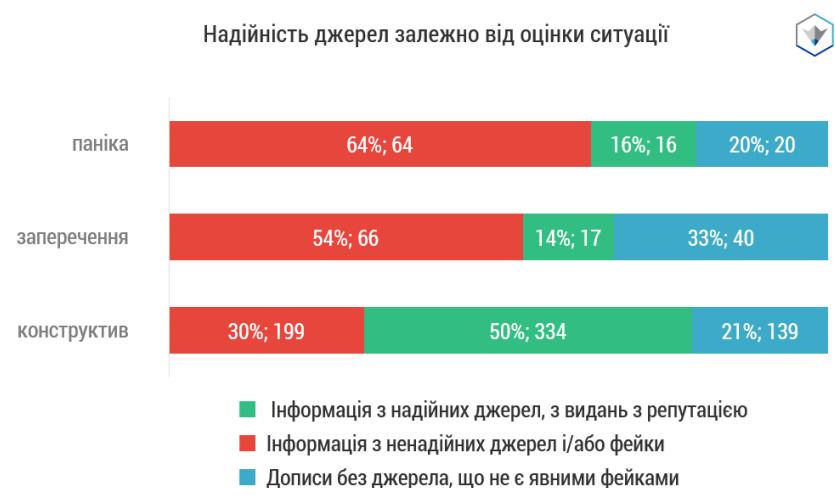

Мал. 1. Надійність джерел залежно від оцінки ситуацї [4].

Основними комунікаційними проблемами в українському суспільстві стала недовіра до влади, дії якої викликали постійну критику, та неконтрольованість інформаційного простору. Не зважаючи на досить високий рівень комунікації з боку владних структур, рівень недовіри переважав, що спричинило поширення фейкової інформації, яка викликала більшу довіру, ніж офіційні заяви з боку перших осіб (див. мал. 2) [4].
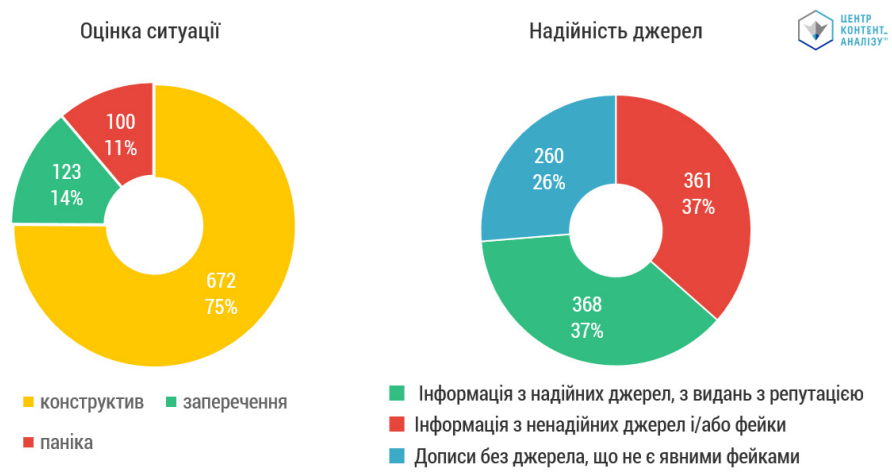

Мал. 2. Оиінка ситуацї̈ користувачали соилереж, а також надійність джерел, які вони використовують [4].

Підтвердженням погіршення психічного здоров'я українців, збільшення загального рівня тривожності є також опутування, проведене А. Широкою (див. мал. 3) [15]. 


\section{ЗДОРОВ'Я НА КАРАНТИНІ}

Дослідження проводилося у квітні 2020 року на 4-5 тижні карантину через поширення COVID-19. Опитано 68 осі6, віком 21-65 років, з них 54\% жінок та 46\% чоловіків.

ДОТРИМАННЯ

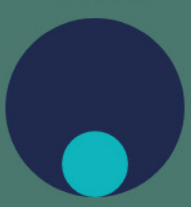

Дотримуються умов карантину

$\mathbf{8 8} \%$

Не дотримуються

$12 \%$
ФІЗИЧНЕ ЗДОРОВ'Я

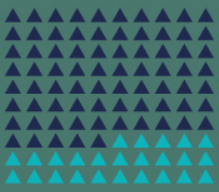

"Моє фізичне здоров'я

змінилося

$75 \%$

"Моє фізичне здоров'я погіршилося"

$25 \%$
ЕМОЧІЙНЕ

САМОПОЧУТT

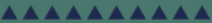

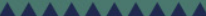

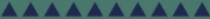

A A A A A A A A A

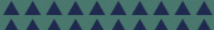

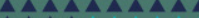

$\mathbf{A} \mathbf{A} \mathbf{A}$

A

"Моє емоційне самопочуття

не змінилося"

$64 \%$

"Моє емоційне самопочуття погіршилося"

$34 \%$

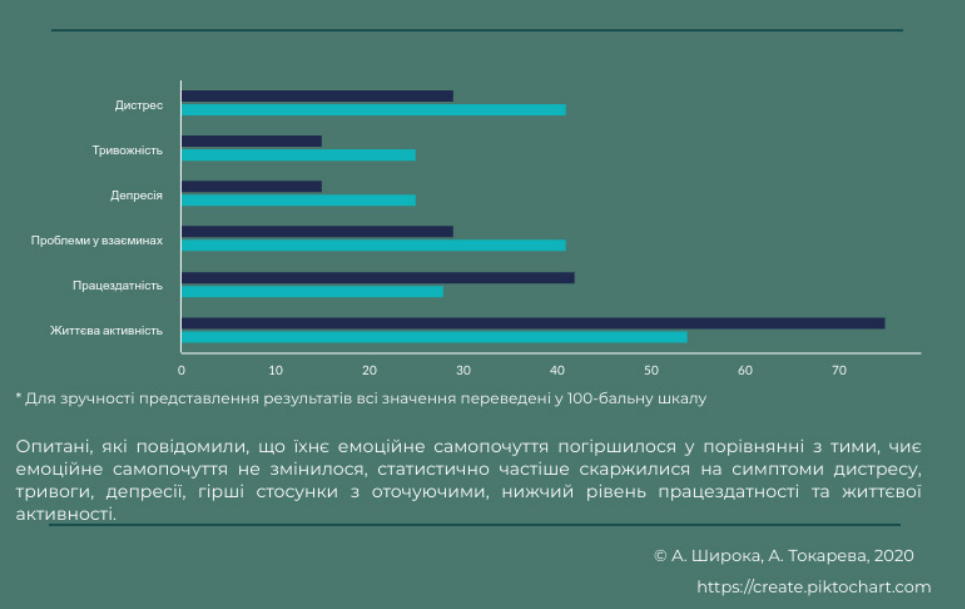

Maл. 3. ВпливCOVID-19 на емоиійне здоров'я [15].

Якість, надійність контенту, який читає та поширює користувач соціальних мереж, е важливими для аналізу причин формування колективної фобії. Дослідження соціологічної компанії InMind засвідчило, що більше 80 \% респондентам траплялася фейкова інформація про Covid-19. Третина з них вважали таку інформацію правдивою, а інша третина, навіть 
усвідомлюючи неправдивість такого контенту, поширювала його поміж інших [17].

Ці вражаючі факти підтверджуються соціологічними дослідженнями волонтерської ініціативи з інформаційної гігієни «Як не стати овочем». Згідно проведеного опитування, 54 \% українських користувачів Facebook публікують неправдиву та маніпулятивну інформацію. Інформація про коронавірус була однією з найпоширеніших фейкових тем [2]. Така безвідповідальна медіактивність українців призводить до формування так званого феномену тривожного інформаційного виру, коли постійна тривога за стан здоров'я, соціальна ізоляція, стрес, невпевненість у майбутньому призводять до суттєвого погіршення психічного здоров'я людей. Психологиня Л. Найдьонова розглядає тривожний інформаційний вир як взаємозараження медійної системи тривожними повідомленнями, в яких міститься інформація про загроиоозу життю [10].

Отже, проблеми протидії фейковій інформації та формування позитивного контенту в умовах пандемії коронавірусу для України є надзвичайно актуальними, оскільки за їх допомогою формуються суспільні настрої та установки.

Значну роль у вирішенні цієї проблеми відіграє свідоме громадянське суспільство. Попри посилення панічних настроїв, спричинених недостовірної інформацією, формується процес суспільної згуртованості. Аналіз медіасередовища демонструє позитивні тенденції до формування та збільшення ініціатив як окремих громадян, так і громадських, благодійних організацій, представників малого, середнього та великого бізнесу, митців, освітян, науковців, медиків, спортсменів щодо наповнення вітчизняного інформаційного простору позитивним контентом. Це дозволяє формувати та розширювати смислові контексти особистості, збільшувати в інформаційному просторі кількість позитивної та корисної інформації. Реалізатори таких ініціатив інколи не усвідомлюють, що їх проєктидопомагають відновити та формувати впевненость у завтрашньому дні, позбавитися відчуття самотності, зменшити рівень тривожності, розпачу та пригніченого стану.

Нами було зроблено спробу систематизувати такі ініціативи та формати їх роботи.

Ініціативи громадських організацій, спрямовані на зменшення поширення негативної та недостовірної інформації про коронавірус.

Соціальний проєкт \#StopCovidUA об’єднав людей різних спеціальностей. Головна мета проєкту не допустити поширення негативної 
та не достовірної інформації про хворобу. Усі учасники руху збирають перевірену інформацію про стан захворюваності; дізнаються, яка допомога потрібна лікарям й звичайним громадянам; здійснюють координацію між лікарнями та тими, хто може допомогти вирішити їхні проблеми. На своїх сторінках у соціальних мережах Facebook та Telegram засновники проєкту публікують тільки перевірену інформацію без зайвого емоційного забарвлення та звітують про свої добрі справи. У межах проєкту було створено гарячу лінію психологічного консультування, коженможе зателефонувати та отримати слова підтримки.

Соціальний проєкт «Науковий метод» заснований організацією INSCIENCE у партнерстві 3 науковцями та журналістами науковопопулярних та суспільних медіа. На думку організаторів, ця платформа може стати корисним інструментом для всіх, хто працює з інформацією. Зокрема, ними було розроблено рекомендації щодо створення якісних, науково-обгрунтованих матеріалів та дописів у соціальних мережах щодо Covid-19, зокрема з точки зору медицини [11].

Ініціативи від масмедіа. Одними з перших до формування позитивного медіасередовища долучився телеканал «ICTV», на сайті якого було створено рубрику «Добрі новини: що хорошого відбувається в світі». Мета проєкту - насичення інформаційного простору добрими новинами, розповідь про перемоги у боротьбі з коронавірусом, про цікаві винаходи та відкриття. Уся інформаціядублюються на сторінках каналу в соціальних мережах [5].

Телеканал «MEGOGO LIVE» запустив серію онлайн-зустрічей 3 українськими зірками шоубізнесу. Проєкт має на меті інформувати переважно молодіжну аудиторію. Трансляції можна переглянути на офіційній сторінці в Instagram, а також на YouTube-каналі. Мета проєкту - комфортне перебування вдома під час карантину, підтримка гарного настрою та запобігання паніці. У межах проєкту зірки в домашній атмосфері розповідають як проводять карантин, діляться творчими планами на майбутнє та влаштовують маленькі концерти [8].

Інтернет медіаресурс - Сайт добрих новин «СВОЇ» - має на меті долучитися до припинення хвилі дезінформації та негативу, а також формувати позитивне медіасередвище, надавати інформацію про цікаві й раніше невідомі факти щодо історії та сьогодення Волині. Основний контент - це позитивна інформація про благодійні ініціативи та людське добро; новини про пандемію та політику відсутні. Проєкт спрямований на тих, хто любить свою країну, цікавиться її історією, 
прагне підтримувати громадські ініціативи та просто втомився від негативних новин [13].

Прикладом боротьби з негативними новинами є соціальний проєкт «\#ШоТам. Твоя пігулка від паніки». Це незалежний онлайн-ресурс, який публікує успішні історії українців та поширюе інформацію про позитивні зміни в суспільстві, країні та світі. Головний заклик медіаpeсурсу: «Допоможи нам поширювати позитивні новини». Проєкт має сторінки в таких соціальних мережах: Facebook, Telegram, Twitter, Instagran та YouTube. Будь-хто може стати ньюсмейкером добрих новин. Таким чином, соціальний проєкт «\#ШоТам. Твоя пігулка від паніки» допомагає збільшити кількість позитивних новин в українському інформаційному просторі [16].

Ініціативи благодійних та громадських організацій, спрямовані на підтримку літніх людей. Їх діяльність під час карантину здебільшого була зосереджена на збиранні грошей на місячні продуктові набори, необхідні ліки, оплату комунальних послуг або оренди житла. Важливим напрямком діяльності є також психологічний супровід, спрямований на формування медіагігієни літніх людей, зберігання спокою, звільнення від тривожності та паніки. Волонтери роздавали пам'ятки з правилами безпеки під час карантину: не виходити з дому, обмежити контакти з людьми, пити більше рідини й мити руки з милом. Серед таких організацій варто згадати благодійну організацію «Життєлюб», благодійні фонди «Старенькі», «Таблеточкі», громадську організацію «Небокрай»,громадську ініціативу «Солідарність», «Спільнота Святого Егідія» .

Схожий формат роботи мають ініціативи благодійних та громадських організацій, спрямовані на підтримку безпритульних, наприклад, всесвітній рух молодих людей «Молодь за мир», «Спільнота Свіятого Егідія», волонтерська організація «Допоможи бездомному» .

Попри первинну мету діяльності зазначених проєктів - надання фінансової, матеріальної та психологічної підтримки літнім та безпритульним людям, ці ініціативи співпрацюють з людьми, які готові стати волонтерами. Аудиторія волонтерів, потенційних волонтерів або тих людей, які в соціальних мережах просто дізнаються інформацію про діяльність таких організацій, також в тій чи іншій мірі знаходяться під впливом інфодемії. Залучення до волонтерських проєктів або інформування щодо волонтерської діяльності сприяють позитивному 
психологічному та емоційному станам людей, усвідомленнюзалученості до доброї справи, яка принесе користь іншим.

Громадські ініціативи, спрямовані на формування позитивних новин про Україну. Одним з таких проєктів є громадська ініціатива «Відкрий Україну через позитив» шляхом пошуку та поширення позитивних новин про Україну. Задля ефективного функціонування було створено інформаційний портал «Добрі новини з України», якийпублікує виключно позитивну інформацію та добрі новини [1].

Іншим прикладом формування позитивних новин про Україну є проєкт «Назустріч одне одному», який належить до місії базової проєктної платформи «Назустріч Сонцю».Мета проекту - розповідати корисні історії про те, як українці допомагають один одному пережити карантин та пандемію коронавірусу. Автори проєкту наголошують наважливості позитивної інформації під час кризових ситуацій, що дозволить зменшитипанічні настрої серед населення у медіапросторі. Корисний та якісний контент допомагатиме іншимгромадянам запускати власну благодійну ініціативу [9].

Висновки. В українському суспільстві набуває обертів тенденція до створення в медіапросторі, зокрема в соціальних мережах, платформ протидії фейковій інформації про коронавірус; онлайн-ресурсів, на яких публікують виключно позитивні, добрі новини. Це має зміцнити психологічне здоров'я українців, їхній моральний стан, зменшити панічні настрої.

У позиціонуванні та діяльності досліджених нами проєктів у соціальних мережах можна виокремити такі тренди: протидія дезінформації, створення позитивного контенту, використання більш емпатійного тону в публікаціях, взаємодопомога, взаємоповага, національна самосвідомість, суспільна згутованість. Окреслені аспекти формування позитивного контенту в медіасередовищі потребують подальшого наукового дослідження та теоретико-практичної розробки.

\section{СПИСОК ВИКОРИСТАНОÏ ЛІТЕРАТУРИ}

1. Добрі новини з України. [Електронний ресурс]. URL :http://ukrainegoodnews.com/pro_nas.html (дата звернення: 5.02.2021).

2. Дослідження рівня базової інформаційної гігієни українських користувачів Facebook [Електронний ресурс] // Як не стати овочем. 2020. 
URL : https://drive.google.com/file/d/18flYOUrX1GB29H4nlUEF_ Qwqul8Y_FgC/view. (дата звернення: 2.02.2021).

3. Дроздов О. Особливості масової свідомості українців в умовах коронавірусної пандемії // Науковий вісник Херсонського державного університету. Серія: «Психологічні науки». 2020. № 3. С. 130-138.

4. Захарченко А. Тривожний діагноз: карантин у соцмережах перетворюється на комунікаційну кризу [Електронний ресурс] // Українська правда. 2020. URL : https://www.pravda.com.ua/columns/2020/03/31/7245861/ (дата звернення: 2.02.2021)

5. Інформаційно-пізнавальна програма "Добрі новини" [Електронний pecypc] // ictv.ua. 2020. URL : https://ictv.ua/ru/tvproject/3679/ (дата звернення: 5.02.2021).

6. Корнієвський О. Громадянське суспільство в умовах пандемії коронавірусу COVID-19: виклики та перспективи розвитку [Електронний ресурс] // Національний інститут стратегічних досліджень. 2020. URL: https://niss.gov.ua/news/statti/gromadyanske-suspilstvo-vumovakh-pandemii-koronavirusu-covid-19-vikliki-ta-perspektivi (дата звернення: 5.02.2021).

7. Кулицький С. Проблеми розвитку економіки України, обумовлені пандемією коронавірусу COVID-19 у світі, та пошук шляхів їх розв’язання (Закінчення. Початок див. у № 8) [Електронний ресурс] // Україна: події, факти, коментарі. - 2020. № 9. С. 47-53. URL: http://nbuviap.gov.ua/images/ukraine/2020/ukr9.pdf (дата звернення: 5.02.2021).

8. Молодіжний телеканал на час карантину запустив онлайн шоу 3 зірками. [Електронний ресурс]. URL :https://blog.megogo. net/ru/2020/03/30/molodezhnyj-kanal-megogo-live-na-vremyakarantina-zapustil-onlajn-shou-so-zvyozdami-stay-home-show/ (дата звернення: 5.02.2021).

9. Назустріч сонцю. [Електронний ресурс]. URL:https://sunwalkers. net/ (дата звернення: 5.02.2021).

10. Найдьонова Л. Медіапсихологічні феномени інфодемії // Досвід переживання пандеміï covid-19: дистанційні психологічні дослідження, дистанційна психологічна підтримка: матеріали онлайн-семінарів 23 квітня 2020 року «Досвід карантину: дистанційна психологічна допомога і підтримка» та 15 травня 2020 року «Дистанційні психологічні дослідження в умовах пандемії covid-19 і карантину» / [за наук. ред. М. М. Слюсаревського, 
Л. А. Найдьонової, О. Л. Вознесенської]. Київ : ІСПП НАПН України, 2020, С. 6-9. URL: https://ispp.org.ua/wp-content/uploads/ Static/dosvid_onl-sem_23-04-20_and_15-05-20_ncov19.pdf (дата звернення: 2.02.2021).

11. Платформа для популяризації наукового підходу і якісної комунікації на теми науки та медицини, зокрема щодо COVID-19 [Електронний ресурс] // Науковий метод. 2020. URL : https://inscience.io/ $\mathrm{nm} /$ \#about (дата звернення: 2.02.2021).

12. Проблеми правового регулювання цивільних відносин в умовах COVID-19 : матер. Всеукр. науково-практичної онлайн-конференції (23 квітня 2020 р.) [Електронний ресурс]. / За заг. ред. д.ю.н., проф. Є. О. Харитонова. Одеса : Фенікс, 2020. 193 с. URL: http://dspace. onua.edu.ua/handle/11300/12616 (дата звернення: 2.02.2021).

13. CВO€ медіа. [Електронний ресурс. URL:https://svoi.media/ (дата звернення: 5.02.2021).

14. Слюсаревський М. Дистанційне зондування суспільної свідомості як передумова адекватної відповіді психологічного співтовариства на виклики пандемії covid-19 // Досвід переживання пандемії covid-19: дистанційні психологічні дослідження, дистанційна психологічна підтримка: матеріали онлайн-семінарів 23 квітня 2020 року «Досвід карантину: дистанційна психологічна допомога і підтримка» та 15 травня 2020 року «Дистанційні психологічні дослідження в умовах пандемії covid-19 і карантину» /[за наук. ред. М. М. Слюсаревського, Л. А. Найдьонової, О. Л. Вознесенської]. Київ : ІСПП НАПН України, 2020, С. 6-9. URL: https://ispp.org. ua/wp-content/uploads/Static/dosvid_onl-sem_23-04-20_and_15-0520_ncov19.pdf (дата звернення: 2.02.2021).

15. Широка А. Психологічна ціна карантину [Електронний ресурс]. 2020. URL : https://health.ucu.edu.ua/news/psyhologichna-tsinakarantynu (дата звернення: 2.02.2021).

16. ШО TAM. [Електронний ресурc]. URL :https://shotam.info/ (дата звернення: 5.02.2021).

17. Щорічне опитування USAID-Internews «Ставлення населення до 3MI та споживання різних типів медіа у 2020 р.» [Електронний ресурс]// Опитування USAID-Internews щодо споживання медіа. 2020. URL : https://internews.in.ua/wp-content/uploads/ 2020/10/2020-Media-Consumption-Survey-FULL-FIN-Ukr-1. pdf (дата звернення: 2.02.2021). 
18. Hardman D., Hutchinson P., Ongaro G. Questioning the Consensus on Placebo and Nocebo Effects // Psychotherapy and Psychosomatics. 2020. № 90 (3). C. 1-2.

\section{REFERENCES}

1. Dobri novyny z Ukrainy [Good news from Ukraine]. Retrieved February 5, 2021 from http://ukrainegoodnews.com/pro_nas.html.

2. Yak ne staty ovochem. (2020). Doslidzhennia rivnia bazovoi informatsiinoi hihiieny ukrainskykh korystuvachiv Facebook [Research of the level of basic information hygiene of Ukrainian Facebook users]. Retrieved February 2, 2021 from https://drive.google.com/file/ d/18flYOUrX1GB29H4nlUEF_Qwqul8Y_FgC/view.

3. Drozdov, O., Drozdova, M. (2020) Osoblyvosti masovoi svidomosti ukraintsiv $\mathrm{v}$ umovakh koronavirusnoi pandemii [Features of mass consciousness of Ukrainians in the conditions of coronavirus pandemic]. Naukovyi visnyk Khersonskoho derzhavnoho universytetu. Seriia: «Psykholohichni nauky», Vol. 3, pp. 130-138. DOI: 10.32999/ksu23123206/2020-3-16.

4. Zakharchenko, A. (2020) Tryvozhnyi diahnoz: karantyn u sotsmerezhakh peretvoriuietsia na komunikatsiinu kryzu [Anxious diagnosis: quarantine in social networks turns into a communication crisis]. Ukrainska pravda. Retrieved February 2, 2021 from https://www. pravda.com.ua/columns/2020/03/31/7245861/.

5. Ictv.ua. (2020). Informatsiino-piznavalna prohrama "Dobri novyny". Retrieved February 5, 2021 from https://ictv.ua/ru/tvproject/3679/.

6. Korniievskyi, O. (2020). Hromadianske suspilstvo v umovakh pandemii koronavirusu COVID-19: vyklyky ta perspektyvy rozvytku [Civil society in the context of the COVID-19 coronavirus pandemic: challenges and prospects]. Natsionalnyi instytut stratehichnykh doslidzhen. Retrieved February 5, 2021 from https://niss.gov.ua/news/statti/gromadyanskesuspilstvo-v-umovakh-pandemii-koronavirusu-covid-19-vikliki-taperspektivi.

7. Kulytskyi, S. (2020) Problemy rozvytku ekonomiky Ukrainy, obumovleni pandemiieiu koronavirusu COVID-19 u sviti, ta poshuk shliakhiv yikh rozviazannia [Problems of economic development of Ukraine caused by the pandemic of coronavirus COVID-19 in the world, and finding ways to solve them]. Ukraina: podii, fakty, komentari. Vol. 9, 
pp. 47-53 Retrieved February 5, 2021 from http://nbuviap.gov.ua/ images/ukraine/2020/ukr9.pdf.

8. Blog.megogo.(2020). Molodizhnyi telekanal na chas karantynu zapustyv onlain shou z zirkamy [The youth TV channel launched an online show with the stars during the quarantine]. Retrieved February 5, 2021, from https://blog.megogo.net/ru/2020/03/30/molodezhnyj-kanal-megogolive-na-vremya-karantina-zapustil-onlajn-shou-so-zvyozdami-stayhome-show/.

9. Nazustrich sontsiu. (2020) Nazustrich sontsiu [Towards the sun]. Retrieved February 5, 2021 from https://sunwalkers.net/.

10. Naidonova, L. (2020). Mediapsykholohichni fenomeny infodemii [Mediapsychological phenomena of infodemia]. Dosvid perezhyvannia pandemii covid-19: dystantsiini psykholohichni doslidzhennia, dystantsiina psykholohichna pidtrymka: materialy onlain-seminariv 23 kvitnia 2020 roku «Dosvid karantynu: dystantsiina psykholohichna dopomoha i pidtrymka» ta 15 travnia 2020 roku «Dystantsiini psykholohichni doslidzhennia v umovakh pandemii covid-19 i karantynu». (pp. 6-9). Kyiv, Ukraina: Instytut sotsialnoi ta politychnoi psykholohii. DOI: http://doi.org/10.33120/QERPASProceding-2020.

11. Naukovyi metod (2020). Platforma dlia populiaryzatsii naukovoho pidkhodu i yakisnoi komunikatsii na temy nauky ta medytsyny, zokrema shchodo COVID-19 [A platform to promote a scientific approach and quality communication on science and medicine, in particular on COVID-1]. Retrieved February 5, 2021 from https:// inscience.io/nm/\#about.

12. Problemy pravovoho rehuliuvannia tsyvilnykh vidnosyn $\mathrm{v}$ umovakh COVID-19. (2020). Vseukrainska naukovo-praktychna onlain-konferentsiia. (pp. 1-193). Odesa, Ukraina: Natsionalnyi universytet «Odeska yurydychna akademiia» Retrieved February 2, 2021 from http://dspace.onua.edu.ua/handle/11300/12616.

13. SVOIe media. (2020). SVOIe media [Your Media]. Retrieved February 5, 2021 from https://svoi.media/.

14. Sliusarevskyi, M. (2020). Dystantsiine zonduvannia suspilnoi svidomosti yak peredumova adekvatnoi vidpovidi psykholohichnoho spivtovarystva na vyklyky pandemii covid-19 [Remote sensing of public consciousness as a prerequisite for an adequate response of the psychological community to the challenges of the covid-19 pandemic]. Dosvid perezhyvannia pandemii covid-19: dystantsiini psykholohichni 
doslidzhennia, dystantsiina psykholohichna pidtrymka: materialy onlain-seminariv 23 kvitnia 2020 roku «Dosvid karantynu: dystantsiina psykholohichna dopomoha i pidtrymka» ta 15 travnia 2020 roku «Dystantsiini psykholohichni doslidzhennia v umovakh pandemii covid-19 i karantynu». (pp. 65-71). Kyiv, Ukraina: Instytut sotsialnoi ta politychnoi psykholohii. DOI: http://doi.org/10.33120/ QERPASProceding-2020.

15. Shyroka, A. (2020). Psykholohichna tsina karantynu [Psychological price of quarantine]. Retrieved February 2, 2021 from https://health. ucu.edu.ua/news/psyhologichna-tsina-karantynu/.

16. ShO TAM (2020). ShO TAM [What's There]. Retrieved February 5, 2021 from https://shotam.info/.

17. Opytuvannia USAID-Internews shchodo spozhyvannia media. (2020). Shchorichne opytuvannia USAID-Internews «Stavlennia naselennia do ZMI ta spozhyvannia riznykh typiv media u 2020 r.» [USAIDInternews Annual Survey "Attitudes of the Population to the Media and Consumption of Different Types of Media in 2020"]. Retrieved February 2, 2021 from https://internews.in.ua/wp-content/ uploads/2020/10/2020-Media-Consumption-Survey-FULL-FINUkr-1.pdf.

18. Hardman, D., Hutchinson, P., Ongaro, G. (2020) Questioning the Consensus on Placebo and Nocebo Effects.Psychotherapy and Psychosomatics. https://doi.org/10.1159/000513466. 